\title{
Investment Banking Services: Ownership Structures, Financial Advisory and Corporate Governance Models
}

\author{
Associate Prof. Renato Giovannini (Corresponding author) \\ Department of Economics and Management \\ Guglielmo Marconi University, Rome, Italy \\ Telephone: +3906377251Ｆax: +390648912028Ｅ-mail: renato.giovannini@unibocconi.it \\ Associate Prof. Vincenzo Capizzi \\ Department of Business Studies and Environment, \\ Eastern Piedmont State University, Novara, Italy \\ Telephone: +390321375438 \\ Fax:+390321375405Ｅ-mail: vincenzo.capizzi@eco.unipmn.it \\ Associate Prof. Gian Marco Chiesi \\ Department of Business Studies and Environment, \\ Eastern Piedmont State University, Novara, Italy \\ Telephone: +390321375443 \\ Fax: +390321375 405 E-mail: gianmarco.chiesi@eco.unipmn.it
}

Received: September 11, $2010 \quad$ Accepted: September 27, $2010 \quad$ DOI: 10.5430/ijba.v1n1p49

\begin{abstract}
This study is based on the premise that mostly large enterprises require investment banking services, due to their complexity and the difficult scenarios in which they operate. Accordingly, we empirically investigate the hypothesis that both the type of ownership structures and the quality of governance are correlated with the demand for specific investment banking services. The analysis is developed by using a proxy for the propensity of enterprises to demand these services, making reference to an extended definition of investment banking activity. The empirical analysis performed on a sample of 150 enterprises showed that the investment banking propensity indicator is significantly correlated with ownership and governance variables. Next, we verify whether companies characterised by greater probability of access to investment banking services show better income performance. However, no conclusive and univocal conclusions can be drawn yet with regard to the linkage between investment banking propensity and performance.
\end{abstract}

Keywords: Investment Banking, Financial Advisory, Corporate Governance, Ownership Structure, Corporate Finance, Private Equity Sponsors

\section{Introduction: the premises and motivations of this study}

Investments banking services are more and more instrumental to the growth and value creation of non financial firms. For example, issuing and placement services represent an irreplaceable way for require capital to sustain investments; advisory services support the growth by external way. However, the extent of the awareness of the usefulness of investment banking services and, consequently, the intensity of their demand for such services is not necessarily homogeneous throughout the business world.

In order to understand which enterprises feed the demand for investment banking services, it can be useful to refer to an evolutionist approach that correlates the quality and variety of the financial policy choices of firms with the latter's stage of development (Caselli, 2001; Brealey \& Myers, 2005). According to the most well-established approaches, it is possible to identify three distinct phases of development, the first of which can be termed "subordinated finance", and is 
a frequent characteristic of very small businesses. In such contexts the financial function operates, as a rule, as an appendix of administration, with tasks limited and aimed essentially to seeking loans. In the second stage of growth, which can be termed "integrated finance", the firm's management has acquired a greater awareness of the need to devote more attention and resources to the financial management of the firm. The financial function is thus given the task of evaluating the financial sustainability of development plans so as to correlate the formation of funding requirements with its internal and external financing capabilities. This imply an analysis of the prospective equilibrium conditions of the financial structure in order to assure the compatibly with its business risks and the development requirements connected with its growth and competitive strategies. Lastly, in the phase that can be described as "strategic finance", the financial function is vested with the task of identifying the ways and means that can enable the enterprise to deal with complex problems, typically of a non-routine type but of decisive importance for the purposes of its survival and competitively on a medium-long term basis. To this end, it becomes crucial to refer to models that make it possible to translate the strategic plans in quantitative and qualitative terms, highlighting on the one hand the resources generated through the performance of their business activities and, on the other, the manners of covering the funding requirements deriving from the pursuit of the plans. So there is an incentive for continuous recourse to investment banking operations, in order to quest for value through external growth, rationalisation of the ownership and financial structure.

For these reasons, this study intends to subject to empirical verification the hypothesis that the type of ownership structure of larger-sized enterprises, on the one hand, and the quality of their governance, on the other, is correlated with the demand for specific investment banking services, such as financial assistance for corporate acquisition purposes, or to organise securities operations on capital markets, or for venture capital openings to private equity and/or institutional investors

\section{The investment banking services industry: business areas, products and services}

The term "corporate investment banking", or simply "investment banking", is used to indicate a set of products and services designed to meet a wide range of complex financial needs other than ordinary funding requirements instrumental to the performance of companies' typical business activities.

It is easy to observe that the investment banking services sector is a very attractive operational area for financial intermediaries, consultancy firms and professionals, due to the high profitability margins - consisting largely of commission - that have historically been achieved by the leaders in this sector.

The problem is due to the commonly definition of investment banking employed, that define a competitive arena with very extensive borders, which includes numerous and highly diverse needs, products, actors, and usable business models. As we shall see in the next paragraph, the literature on financial intermediation seldom examines investment banking as an industry but chooses to investigate it in narrower terms, focusing on one specific business area or another from case to case.

As shown in Table 1, investment banking services sector can be disaggregated into five strategic business areas (Capizzi, 2006): Capital markets, Corporate finance, Merchant banking, Project finance, Risk management.

First of all, it must be clearly understood that the concept of complexity refers directly to the fact that, in relation to the routine financing needs of firms which are typically met through the more traditional lending activities. Moreover, it must be noted that the approach chosen here, although very broad, gives rise nonetheless to the exclusion of some significant areas of financial intermediaries' operativity, which with reference to an "extended" interpretation of investment banking it would not have been inappropriate to take into account: for instance, services such as asset management and private banking, retail brokerage, real estate and insurance. They have been excluded because they are not products or services dedicated exclusively to meeting financial needs connected with the performance of the typical activity of a firm.

\section{Demand for investment banking services: a review of the literature}

As mentioned in the introduction, this paper aims to investigate the role and raison d'être of investment banking activity in the framework of economic and financial systems. Although investment banking is not univocally defined, as we have already seen, it has been extensively discussed in the literature; that allow us to distinguish several successive lines of contributions. First of all, we must make it clear that in this context we refer to the portion of literature that has sought to approach the issue by focussing on the role of "qualified intermediary" performed by the advisor, independently of whether the institution involved in a given operation is a commercial bank or an investment bank and of the specific type of business area involved (capital markets, corporate finance, merchant banking).

In this sense, the first class of explanations provided to justify the existence of financial intermediaries in the investment banking services area hinges on the ability of the latter to reduce, even to a significant extent, the transaction costs 
typical of both the capital market and the market for corporate control. The fundamental contributions of Gurley and Shaw (1960), Benston and Smith (1976) and Fama (1980) had already cast light on the important role played by intermediaries who are able, thanks to their professionalism, knowhow and "production technology", to ensure compatibility between the preference schemes of the counterparties who enter into a transaction regarding the negotiation of financial contracts (Santomero, 1984; Chan, Greenbaum \& Thakor, 1986; Hellwig, 1991; Bhattarcharya \& Thakor, 1993; Freixas \& Rochet, 1997; Allen \& Santomero,1997, 1999).

According to a second class of explanations, financial intermediaries perform an essential role in the investment banking services market due to their superior ability to produce and manage information regarding the aspects in which the interests of the parties involved in a given negotiation normally diverge (Servaes \& Zenner, 1996; Gompers \& Lerner, 2004).

A third class of explanations, although also referring to the theoretical category of informational asymmetries, justifies the existence of advisors in investment banking operations not only on the basis of their greater efficiency in collecting and processing information, but rather on that of the "certifying" effect, founded essentially on their own reputation, whereby they assure the validity of a given transaction. The literature on financial intermediation and securities underwriting has produced numerous contributions that analyse the effect produced by the underwriter's reputation on the effectiveness of a given placement, on pricing and on short and long term performance (Smith, 1986; Kroszner \& Rajan, 1994; Hebb, 1999; Puri, 1999; Ritter, 2003; Carter \& Manaster, 1990; Bowers \& Miller, 1990; Hunter \& Walker, 1990; McLaughlin, 1990, 1992; Meggison \& Weiss, 1991; Brav \& Gompers, 1997; Dai, 2007; Arikawa \& Imad'Eddine, 2006). More recently, Katz (2008) showed that firms in which closed investment funds are shareholders show better book performances over time than firms in whose capital no private equity funds are present.

A fourth class of explanations inserts the problem into the framework of a context of multiperiod firms-intermediary relationships (Srinivasan, 1999; Rau, 2000; Lastly, Saunders \& Srinivasan, 2001; Michaely \& Shaw, 1994; Beatty \& Ritter, 1986; and Dunbar, 2000; Krignam et al., 2001).

In brief, from the above review of the literature it can be seen that investment banking activities play a fundamental role in finding solutions for complex financial and strategic needs that are not necessarily related to an enterprise's routine activity but are instrumental to its future business growth and development.

\section{Empirical analysis: investigational premises and objectives}

Investment banking plays an important role in resolving complex financial requirements, often not related to the ordinary activities of the enterprises but necessary to ensure their growth. The demand for these services consists, in general, of mature enterprises of particularly significant dimensions. The need for large amounts of capital to carry out new investments and the possibility of directly accessing the financial market are conditions can occur only in large firms. These services are outside the scope of corporate banking and traditional lending and are useful to enterprises seeking agreement with shareholders on the goal of value creation. In addition, the granting of credit does not constitute the ultimate objective that justifies the efforts made by the investment banks in terms of planning and offering the services typically pertinent to this sector. This characteristic differentiates such operations from those typically conducted in the commercial banking sphere.

While many contributions underlines that large companies are the greatest recipients of these services, it is interesting to investigate the existence of characteristics that foster the propensity to engage in investment banking operations. Although the evolutionist approach to the financial function illustrated in the first section stresses that these services are necessary to combine growth and profitability during the "strategic finance" phase, it is not possible to maintain that all large firms enterprises are actually in this phase of development. This depends, in fact, on the strategic vision of their management and significant shareholders, who may instead have vested the financial function with tasks more typical of those of "integrated finance. And as the strategic approach pursued by an enterprise is ultimately due to the characteristics of its management and significant shareholders, it is worthwhile for us to investigate the existence of linkages between ownership, corporate governance, the development of the financial function and recourse to investment banking operations. Ownership and governance structures that attribute to the financial function a strategic role in the company's management foster the acceptance of financial valuation criteria. This induces the company to develop a symbiotic relationship with the financial market, enabling its continuous recourse to sophisticated financial services.

It is possible to imagine that greater presence of financial intermediaries, namely banks, investment trusts and insurance firms amongst a company's shareholders would foster a management approach more orientated to fully exploit external potential for growth. Moreover, the presence of independent directors could also positively influence the presence of a 
management characterised by a strategic vision of this type.

The linkage between ownership and recourse to investment banking can be explained with reference to the separation between ownership and control. In these contexts the managers are in fact independent of the shareholders and can pursue the goal of value creation. Thus it appears worthwhile to investigate the following research question:

4.1 Do certain ownership structures favour recourse to investment banking services?

It is possible to expect that enterprises with widely scattered shareholders are more oriented towards engaging in investment banking operations to pursue growth by acquiring innovative enterprises. With reference to governance structures, it is possible to postulate that a greater presence of independent directors can be associated with greater attention towards the requirements of the capital market. Consequently, the second research question to be examined is the following:

\subsection{Do certain governance structures favour recourse to investment banking services?}

One may expect that enterprises with governance structures characterised by a more pervasive presence of independent directors, have a greater propensity to maintain correct relations with the financial market, allowing a growth by external way financed either by debt or equity.

Adopting as our model the structure-conduct-performance paradigm, it can be assumed that the aforementioned two research questions aim to verify the linkage between structure and conduct, meaning that they seek to ascertain whether certain ownership or governance structures influence the behaviour of management and induce it to recourse to investment banking operations. However, to confirm the advisability of recourse to investment banking services it is also necessary to investigate the linkage between conduct and performance, i.e. to ascertain whether recourse to investment banking services makes it possible to improve the performance. The research question to be verified is therefore:

\subsection{Does recourse to investment banking operations favour the achievement of better performances?}

It can be expected that firms characterised by greater propensity to utilise investment banking services would show the best performances. If the results confirm these expectations, this would confirm the validity of the structure-conduct-performance paradigm as a whole: if the enterprises that make the most use of investment banking operations are those that obtain the best performances, and if certain ownership and governance structures favour recourse to investment banking, it can be concluded that these setups are potentially able to obtain better performances.

A further investigation of the linkage between behaviour (recourse to investment banking operations) and performance is to test whether the market rewards, in terms of higher valuation, those firms that have most recourse to investment banking operations. The research question to be answered is thus the following:

\subsection{Is recourse to investment banking rewarded by better valuations of securities?}

If the postulated linkage is confirmed, this would mean that the market reflect in terms of pricing the better opportunities linked to the adoption of a management policy oriented towards the pursuit of growth supported by these types of operations.

\section{Sample and methodology}

In order to empirically test the research questions formulated above, we use a sample consisting of 150 large European enterprises, with registered offices in Italy, Germany, France, Spain and UK. We have employed this selection criterion, instead of an approach based on the market on which an enterprise is effectively listed, so as to obtain sub-samples that are homogeneous in terms of the normative constraints that can influence the structuring of its ownership and governance. For each country, we have considered the thirty listed non-financial companies with the highest market value at the end of 2007. This has made it possible to generate a sample consisting of enterprises of considerable size and whose financial function should be in the "strategic" phase. Table 2 provides some descriptive statistics of the firms in the sample.

In order to carry out an empirical investigation of the research questions stated above, it is necessary to express in quantitative terms the various typically qualitative aspects relative to the ownership and governance configurations and to the propensity to resort to investment banking. To perform the empirical verifications, the following variables have been employed:

- Investment banking propensity indicator

- Ownership configuration indicator

- Presence of independent directors (corporate governance) indicator 
- Profitability indicator

- Market valuation indicator

In the following sub-paragraphs we shall describe the indicators in greater detail.

\subsection{Investment banking propensity indicator}

The measurement of recourse to investment banking is one of the most original features of this research. The analysis of the operations effectively conducted and of the propensity to use these services can be most easily investigated with reference to individual cases, but it's more difficult to extend it to a larger sample in order to obtain empirical confirmation. For this reason, it is necessary to introduce variables that can approximate the propensity to resort to investment banking operations. With reference to the taxonomy proposed in the second section, to implement this measurement we take into consideration three business areas: Corporate Finance, Capital Markets and Merchant Banking. For each of the three business areas indicated above, variables were identified that allow determining, for each enterprise in the sample, the propensity to resort to such services.

\subsubsection{Corporate Finance}

To measure the propensity to utilise the Corporate Finance segment, the following variables were employed:

I) Number of Enterprises in the Group (at the end of 2007 - Source: Amadeus Data Bank). The larger the number of enterprises is in the group, the greater the group's propensity will be to resort to operations for the purposes both of growth via external acquisitions and for restructuring significant shareholding packages.

II) Number of M\&A Operations as Buyer (period: 2005/2007 - Source: Amadeus Data Bank). The greater the number of merger and acquisition operations carried out by the group in the past, the greater its propensity will be to resort to investment banking operations. If in the past a group has grown chiefly by acquisitions, it is probable that it will continue to pursue this growth policy in the future.

III) Number of M\&A Operations as Seller (period: 2005-2007 - Source: Amadeus Data Bank). The assumption on which this is based is also the same as the previous one, although it is focussed on selling rather than purchasing.

The three-way subdivision of the variables associated with M\&As is linked to the important role played by these operations in the logic of the "strategic finance" phase. Focussing solely on operations carried out as buyer could have meant neglecting certain aspects deemed explanatory of the "financial" behaviour of enterprises and, as such, of importance in measuring their investment banking propensities. Considering M\&As from the standpoint of sellers allows to verify whether the company is engaged in a constant quest to optimise the use of capital. Considering the number of firms belonging to the group can be viewed as either a forward looking or a backward looking variable. From the first point of view, the greater the number of enterprises in the group, the greater the probability of the enterprise engaging in M\&A operations in future, in terms of sales and/or mergers. From the second, the presence of a large number of enterprises can be considered a proxy for the propensity to grow by external expansion.

\subsubsection{Capital Markets}

To measure the propensity to resort to Capital Markets operations, the following proxies have been used:

IV) Stock Volatility (2007 - Source: Amadeus Data Bank): the use of this proxy is linked to the possibility that enterprises may use investment banking services to stabilise stock quotations. The greater the degree of stock volatility, the higher the probability of using services of this type.

V) Bond to Stock Ratio (end 2007 - Source: Amadeus Data Bank and author's data-processing): the higher the level of corporate bonds in relation to the market value of equity, the greater the propensity of the firm to use advisory services for issuing bonds.

VI) Number of buy back operations (period: 2005-2007 - Source: Amadeus Data Bank): the higher the number of buy backs, the higher the probability of future recourse to this type of operation to distribute money to shareholders by means alternative to the distribution of dividends.

\subsubsection{Private equity}

To measure the propensity to resort to Private Equity operations, the following proxy has been used:

VII) Percentage of capital held by Financial Intermediaries (end 2007 - Source: Amadeus Data Bank). This proxy is used to measure the tendency to be the object of private equity operations, meaning the acquisition of significant amounts of stock by investment trusts, pension funds, banks, insurance firms or other financial intermediaries.

Each enterprise in the sample was assigned a score, equal to 2 (high), 1 (average) or 0 (low), for each of the seven 
proxies linked to investment banking services. The cut-offs are based on structuring each proxy into equal tertiles with reference to the total sample. The propensity to use investment banking (PIB) for each enterprise in the sample has been calculated by summating the scores obtained for each of the seven proxies described above. Lastly, to obtain an indicator expressed in percentage terms, the score obtained by each individual firm has been divided by the maximum score that an enterprise could have achieved, i.e. 14. The average result obtained for the various proxies and for PIB indicator is showed in Table 3.

\subsection{Ownership structure indicators}

To conduct an empirical test of the relationship between the linkage to engage in investment banking operations and the feature of the corporate ownership structure it is necessary to use a variable that can provide a quantitative synthesis of the ownership features. To construct this indicator we used BVDEPii (Bureau Van Dijk Editor Publishing Independence Indicator) provided by Amadeus Data Bank. It's a judgement graded on an alphabetic scale (A, B, C, D, U) which assigns the highest score to the firms that are characterised by the highest level of management independence in relation to their shareholders. The indicator assigns a score of A to a firm when the data bank indicates that it has several significant shareholders, none of whom hold, either directly or indirectly, more than $25 \%$ of the company's capital stock. An A score can, in addition, be further modulated as A+, A or A-. An A+ score is assigned to companies known to have at least 6 significant shareholders with equity holdings below 25\%; an $\mathrm{A}$ is assigned when they are known to number 4 or 5. Lastly, a score of A- is given to companies known to have 1 to 3 significant shareholders with holdings of less than $25 \%$. The logic followed by the Amadeus data bank in assigning the various A scores is thus linked to the probability of having overlooked, due to the inadequacy of the documentation provided in financial statements or other sources used, shareholders with holdings in excess of $25 \%$. The greater the number of known shareholders, the lower the probability that the data base has overlooked shareholders with over $25 \%$ of the capital stock. The managers of firms assigned an A score are considered relatively independent of their company's shareholders.

A score of B is assigned to enterprises characterised by the presence of shareholders who hold less than $50 \%$ of the capital stock, i.e. whose holdings do not meet the legal requirements for control. In addition, B scores are further articulated into B+, B and B-following the same criteria used for A scores.

A score of $\mathrm{C}$ is assigned to enterprises that have a shareholder who holds over $50 \%$ of the capital stock, but on an indirect not a direct way. A score of $\mathrm{C}+$ is assigned to enterprises for which the database indicates the presence of direct shareholdings, by shareholders other than a controlling shareholder, that amount to over $50 \%$ of the capital stock. This circumstance in fact enables us to exclude with certainty the presence of direct holdings on the part of the controlling party that are not detected by the database. A score of $\mathrm{D}$ is instead assigned to those enterprises that have a shareholder who holds, on a direct way, over $50 \%$ of the company's capital stock, thus meeting the conditions for legal control. Lastly, a score of $U$ is assigned to firms with regard to which the data base has no information on shareholders (this score is frequent in the case of smaller, unlisted companies).

To produce empirical verifications regarding the linkage between ownership structure and propensity to engage in investment banking operations, it is necessary to grade the judgements expressed in alphabetical terms on a numerical scale. To take into account the aforementioned possible database information gaps which could vitiate the soundness of judgement regarding independence of management from ownership, we have considered it advisable to take into account not only the alphabetic score but its finer gradings as well. Accordingly, to convert the judgements from alphabetic into numerical scores the conversion criterion shown in Table 4 have been used. The maximum value, equal to 10 , is assigned to enterprises with a score of $\mathrm{A}+$, and the minimum value, equal to 2, to those with a score of $\mathrm{D}$. Applying the conversion criterion shown in Table 4 to the previously described sample of 150 enterprises gives the results shown in Table 5.

\subsection{Presence of independent directors (Corporate Governance indicator)}

To translate into quantitative terms the features of corporate governance we use the percentage of independent directors in relation to the total members present in the Board of Directors, in the case of a traditional structure, or in the Supervisory Committee, in the case of a dual governance system. The data on the presence of independent directors in the firms belonging to the sample are provided by Farina, Schwizer and Stefanelli (2009). This information refers to the thirty largest listed enterprises in the five countries examined, inclusive however of financial intermediaries. As can be seen in Table 6, since 39 of the 150 firms present in the latter database are financial, the samples coincide only with regard to 111 enterprises. Moreover, it must be noted that German company law does not require the explicit indication of independent directors. For this reason, for the analysis conducted in this context we have eliminated the German enterprises from the sample; and in addition, no data is available on 2 French firms. As a result, we are left with only 85 enterprises for which it is possible to perform the verification of the linkage between investment banking propensity and 
governance configurations.

The Table 6 shows the average values of DIR (presence of independent directors on board) both for each of the four countries analysed (Germany excluded), and for the sub-sample of 85 enterprises.

\subsection{Profitability indicator}

To test the linkage between investment banking propensity and the corporate performance we use an indicator based on corporate accounts data, namely the 2007 ROE (Return on Equity). Adopting an accountancy indicator instead of financial market performance should allow a measurement more prudent and less linked to short-term fluctuations. Table 7 shows the average results both for the total sample and for the countries sub-samples.

\subsection{Market valuation indicator}

To ascertain whether the propensity for investment banking is rewarded by the financial market with better valuations of the company's stock, we have employed the end 2007 Price to Book Value indicator provided by the Amadeus Data Bank. Table 8 shows the average results both for the sample as a whole and for the sub-samples for the various countries examined. The sample analysed consists of 149 units out of the total number of 150 , as we decide to exclude a UK enterprise due to the marked divergence of the value given by the data base (equal to 259.72) in relation to the average values obtained both for the UK sub-sample and for the sample as a whole.

\section{Analysis results}

This paragraph describes the results found for the four research questions previously discussed, namely:

- Do certain ownership structures favour recourse to investment banking services?

- Do certain governance structures favour recourse to investment banking services?

- Does recourse to investment banking operations favour the achievement of better performances?

- Is recourse to investment banking rewarded by better valuations of securities?

In the following sub-paragraphs we shall describe the analysis results in greater detail.

\subsection{Do certain ownership structures favour recourse to investment banking services?}

The object of this analysis is to verify empirically whether more efficient ownership structures favour recourse to investment banking operations. For the empirical verification of this hypothesis we conducted a univariate linear regression analysis based on the following formula:

$$
P I B=\alpha+\beta_{1} \cdot B_{V D E P} i i+\varepsilon
$$

In (1) the dependent variable consists of the propensity to resort to investment banking services (PIB), while the independent variable is the BVDEPii. The hypothesis to be verified is whether in the presence of ownership structures deemed most efficient there is an increased propensity to resort to investment banking operations. Table 9 shows that the coefficient associated with the BVDEPii is positive with a significance level of $99 \%$.

The same analysis was conducted with reference to the smaller sample of 85 enterprises so as to allow subsequent comparison with the results obtained in the empirical check regarding the linkage between investment banking propensity and the presence of independent directors. The results shown in the second column are analogous to those given in the first column. On the basis of the findings in Table 9 it is possible to maintain, with reference to the sample examined, that enterprises with ownership structures characterised by better judgement in terms of BVDEPii are associated with a higher propensity to resort to investment banking operations.

\subsection{Do certain governance structures favour recourse to investment banking services?}

This analysis is based on the assumption that the presence of independent directors favours transparent governance, hence better relations with the financial market and greater recourse to investment banking operations. To verify this linkage we used (2), a univariate linear regression with investment banking propensity (PIB) as the dependent variable and the presence of independent directors in relation to total directors as the independent variable (DIR).

$$
P I B=\alpha+\beta_{2} \cdot D I R+\varepsilon
$$

The first column in Table 10 shows that DIR is positively and significantly linked to PIB. In other words, it is possible to maintain that the presence of a higher number of independent directors favour the recourse to investment banking operations. However, on the whole the model is able to explain only a small portion of the dependent's overall variability, equal to $5 \%$, as indicated by the value assumed by the adjusted-R 2 . 
Taking into account on the one hand the convergence in explaining the investment banking propensity by the two indicators used as independent variables in (1) and in (2) and, on the other, the lower significance level of the one linked to the presence of independent directors, a bivariate analysis was carried out, using regression equation (3), which makes joint use of the two previously employed independent variables to explain the propensity to resort to investment banking.

$P I B=\alpha+\beta_{1} \cdot B V D E P_{i i}+\beta_{2} \cdot D I R+\varepsilon$

The objective is to ascertain whether both of these variables contribute significantly towards the interpretation of investment banking propensity or whether the contribution of one factor is absorbed by the other. The second column in Table 10 shows the results obtained with this type of analsyis with reference to the sample consisting of 85 enterprises. The addition of variable BVDEPii renders the contribution associated with the presence of independent directors insignificant. The joint analysis thus shows that the most appropriate indicator for interpreting the propensity to resort to investment banking operations is the linked to ownership and not to governance.

\subsection{Does recourse to investment banking operations favour the achievement of better income performances?}

For empirical verification of the hypothesis that the profitability of a firm is positively affected by higher propensity to resort to investment banking we used (4), a regression equation that takes 2007 ROE as its dependent variable and PIB as its independent variable:

$R O E=\alpha+\beta_{3} \cdot P I B+\varepsilon$

The results obtained in this analysis, which extended over the full sample of 150 firms, are given in Table 11 and they don't show any linkage between investment banking propensity and profitability: the coefficient associated with the independent variable is not statistically significant. Accordingly, on the basis of the data it is not possible to confirm the existence of the linkage between profitability and propensity to resort to investment banking that had previously been postulated. In this regard, it can be argued that the results arising from the performance of investment banking operations can only become clear in the medium term, while they are not evident with reference to the annual performance figures analysed in this context.

\section{4) Is recourse to investment banking rewarded by better valuations of securities?}

The last regression analysis carried out in this study aims to verify whether the financial market rewards with more favourable valuations the securities of the firms most oriented towards carrying out investment banking operations. We conducted a univariate regression analysis modelled as shown in (5) which foresees PIB as independent variable. As dependent variable it employs PBV, i.e. the end 2007 Price to Book Value, on the basis of the assumption that a higher value of this ratio indicates which firms are more favourably valued.

$P B V=a+\beta_{4} \cdot P I B+\varepsilon$

The results obtained in the analysis are shown in Table 12 and refer, as already mentioned, to a sample consisting of 149 enterprises, due to the exclusion of an outlier. This analysis doesn't produce significant results: the coefficient associated with the independent variable to PIB is not statistically significant. It is possible, however, to maintain that as already mentioned in the case of the linkage between investment banking propensity and profitability, the results arising from operations of this type only become apparent in the medium term, while they are not evident in the short-term time span employed in this context.

\section{Concluding remarks and suggestions for future research}

The aim of this study was to identify the links existing between the demand for investment banking services expressed by business enterprises, on the one hand, and the ownership and governance configurations of a sample of listed companies from five different European countries on the other.

The chief premise on which this study was based is that investment banking services, if correctly planned and provided, are qualified and feature high added value, and as such, are able to resolve complex problems of a non-routine nature in the life of business enterprises which, if not adequately handled, could significantly affect their growth and future development.

The second premise underlying this study is that large-sized, listed companies that make financial policy decisions on the basis of a model that can be termed "strategic finance" have the appropriate features and incentives to appreciate and demand investment banking services.

We therefore decided to subject a series of hypotheses to empirical verification, proceeding step by step in keeping with 
a structure-conduct-performance approach. Firstly, we postulated that specific ownership and governance configurations influence the conduct of the enterprise by increasing its propensity to engage in investment banking operations to combine development and profitability. Next, we examined the hypothesis that recourse to investment banking operations favours the achievement of better income performance and is therefore rewarded by the financial market with better valuations of the enterprise's securities.

The empirical analysis carried out on a sample of 150 enterprises showed that the analysis model based on the adoption of the investment banking propensity indicator was significant in relation to the variables of ownership and governance structures. Ownership and governance configurations of a more efficient type were indeed found to be associated to an increased propensity for investment banking. On the other hand, no conclusive indications can be drawn with regard to the relationship between investment banking propensity and performance, as the results of the analysis in this sphere were not statistically significant. Analogous results were found with regard to financial market valuation. In this regard, it could be maintained that the results arising from the performance of investment banking operations can be read only in a medium-term horizon.

Although not all of the assumptions tested were validated by the empirical analysis performed, this paper nonetheless constitutes a first step towards the systematisation of a theory of investment banking, interpreting this term in a broader sense than is usually the case and without linking it to any specific business models or legal forms of financial intermediaries that perform such activities. In this sense, future research should continue to attempt to justify, in an even more complete way, the raison d'etre of investment banking activities, by identifying proxies that are increasingly able to represent in a complete manner the full range of investment banking services. Ownership structures that are independent of management and evolved governance systems constitute in this sense, also in the light of the findings of this study, features that can assure the presence of a high propensity to make use of investment banking activities.

\section{References}

Aggarwal, R. (2000). Stabilization Activities by Underwriters after Initial Public Offerings. The Journal of Finance 55, 1075-1103

Allen, F., and Santomero, A.M. (1997). The Theory of Financial Intermediation. Journal of Banking and Finance 21, 1461-1485.

Allen, F., and Santomero, A.M. (1999). What Do Financial Intermediaries Do? Working paper, The Wharton School, University of Pennsylvania.

Arikawa, Y., and Imad'Eddine, G. (2006). Who provides certification effect in Japan? Evidence from IPOs on the Jasdaq, Mothers and Hercules. Working paper, Waseda University.

Battacharya, S., and Thakor, A. (1993). Contemporary Banking Theory. Journal of Financial Intermediation, 3, 2-50.

Beatty, R., and Ritter, R. (1986). Investment banking, reputation, and underpricing of initial public offerings. Journal of Financial Economics, 15, 213-232.

Benston, G., and Smith, C.W. (1976). A Transactions Costs Approach to the Theory of Financial Intermediation. The journal of Finance, 31, 215-231.

Bowers, H.M., and Miller, R. (1990). Choice of Investment Banker and Shareholder Wealth of Firms Involved in Acquisitions. Financial Management, 19, 34-44.

Brav, A., and Gompers, P. (1997). Myth or reality? The long-run performance of IPOs: evidence from venture capital-backed companies. The Journal of Finance, 52, 1791-1821.

Carter, R., and Manaster, S. (1990). Initial Public Offerings and Underwriter Reputation. The Journal of Finance, 45, 1045-1067.

Capizzi, V. (2006). Investment banking: un settore con elevata varietà di operatori, prodotti, business models. Economia \& Management, 1, 52-56.

Caselli, S. (2001). Corporate banking per le piccole e medie imprese, Rome: Bancaria Editrice.

Chan, Y.S., Greenbaum, S., and Thakor, A. (1986). Information Reusability, Competition and Bank Asset Quality. Journal of Banking and Finance, 10, 243-253.

Dai, N. (2007). Does investor identity matter? An empirical examination of investments by venture capital funds and hedge funds in PIPEs. Journal of Corporate Finance, 13, 538-563. 
Dunbar, C.G. (2000). Factors affecting investment bank initial public offering market share, Journal of Financial Economics 55, 3-41.

Fama, E. (1980). Banking in the Theory of Finance. Journal of Monetary Economics, 6, 39-57.

Freixas, X., and Rochet, J.C. (1997). Microeconomics of banking. Cambridge: MIT Press.

Gompers, P., and Lerner, J. (2004). The Venture Capital Cycle. Cambridge: MIT Press.

Gurley, J.G., and Shaw, E.S. (1960). Money in a Theory of Finance. Washington, D.C.: The Brookings Institution.

Harris, M., and Raviv, A. (1991). The Theory of Capital Structure. The Journal of Finance, 46, 297-355.

Hebb, G. (1999). Commercial Bank Involvement in Equity Underwriting. Working paper, St Mary’s University, Canada.

Hebb, G., and Mackinnon, G. (2004). Valuation Uncertainty and IPOs: Investment bank versus Commercial bank underwriters. Journal of Economics and Finance, 28, 68-87.

Hellwig, M. (1991). Banking, Financial Intermediation and Corporate Finance. In A. Giovannini, C.P. Mayer (Eds.), European Financial Integration. Cambridge: Cambridge University Press.

Hunter, W.C., and Walker, M.B. (1990). An Empirical Examination of Investment Banking Merger Fee Contracts. Southern Economic Journal, 56, 1117-1130.

Jensen, M. (1986). Agency Costs of Free Cash Flows, Corporate Finance, and Takeovers. American Economic Review, 76, 323-329.

Katz, S. (2008). Earnings Quality and Ownership Structure. The Role of Private Equity Sponsors. NBER Working Paper Series, n. 14085, Cambridge.

Krignam, L., Shaw, W.H., and Womack, K.L. (2001). Why do firms switch underwriters? Journal of Financial Economics, 60, 245-284.

Kroszner, R., and Rajan, R. (1994). Is Glass Steagall Act Justified? A Study of the U.S. Experience with Universal Banking Before 1933. American Economic Review, 84, 810-832.

Kuhn, R.L. (1990). Investment Banking. The Art and Science of High-Stakes Dealmaking. New York: Harper \& Row.

McLaughlin, R.M. (1990). Investment Banking Contracts in Tender Offers: an Empirical Analysis. Journal of Financial Economics, 28, 209-232.

McLaughlin, R.M. (1992). Does the Form of Compensation Matter? Investment Banker Fee Contracts in Tender Offers. Journal of Financial Economics, 32, 223-260.

Megginson, W.L. (1997). Corporate Finance Theory. Reading: Addison-Wesley.

Megginson, W.L., and Weiss, K.A. (1991). Venture Capitalist Certification in Initial Public Offerings. The Journal of Finance, 46, 879-903.

Michaely, R., and Shaw, W.H. (1994). The pricing of initial public offerings: Tests of adverse-selection and signalling theories. Review of Financial Studies, 7, 279-319.

Puri, M. (1999). Commercial banks as underwriters: Implications for the going public process. Journal of Financial Economics, 2, 133-163.

Rau, R. (2000). Investment Bank Market Share, Contingent Fee Payments, and the Performance of Acquiring Firms. Journal of Financial Economics, 56, 293-324.

Ritter, J.R. (1991). The Long Run Performance Of Initial Public Offerings. The Journal of Finance, 46, 3-27.

Ritter, J.R. (1998). Initial Public Offerings. Contemporary Finance Digest, 1, 5-30.

Ritter, J.R. (2003). Investment Banking and Securities Issuances. In G. Constantinides, M. Harris, E. Stultz (Eds.), Handbook of the Economics of Finance. Amsterdam: North-Holland.

Santomero, A.M. (1984). Modelling the banking firm. Journal of Money, Credit and Banking, 16, 576-602.

Saunders, A., and Srinivasan, A. (2001). Investment Banking Relationships and Mergers Fees. Working paper, New York University.

Schwizer, P., Farina, V., and Stefanelli, V. (2009). Dimension, structure and skill mix in European boards. In V. Capizzi, D. Corrado, P. Schwizer, A. Zattoni (Eds.), Ownership and governance in large corporate groups: a comparative study in five European countries. Milan: Research Division-SDA Bocconi. 
Servaes, H., and Zenner, M. (1996). The Role of Investment Banks in Acquisitions. The Review of Financial Studies, 9, 787-815.

Smith, C.W. (1986). Investment Banking and the Capital Acquisition Process. Journal of Financial Economics, 15 , 3-29. Srinivasan, A. (1999). Investment banking relationship: theory and evidence from merger fee. Working paper, NYU.

Table 1. The Investment Banking Sector: business areas, products and services

\begin{tabular}{|c|c|}
\hline Business Areas & Products \& Services \\
\hline Capital Markets & $\begin{array}{l}\text { Primary Market operations } \\
\text { - equity capital market services (issuing and placement, research, } \\
\text { sponsorship, post listing support) } \\
\text { - debt capital market services (issuing and placement, securitization, } \\
\text { research...) } \\
\text { Secondary Market operations } \\
\text { - equity capital market services (selling, dealing, brokerage, market } \\
\text { making, asset management) } \\
\text { - debt capital market services (selling, dealing, brokerage, market } \\
\text { making, asset management) }\end{array}$ \\
\hline Corporate Finance & $\begin{array}{l}\text {-ownership reallocation services (mergers and acquisition, } \\
\text { LBOs/MBOs, } \\
\text { - ownership structure reorganisation services (spin-offs, carve-outs, } \\
\text { splits-ups, admission of new partners } \\
\text { - company crisis restructuring services } \\
\text { - financial advisory services }\end{array}$ \\
\hline Merchant Banking & $\begin{array}{l}\text { - equity holdings in companies in the start-up, early stage (venture } \\
\text { capital) } \\
\text { - equity holdings for growth or ownership base restructuring purposes } \\
\text { (private equity) }\end{array}$ \\
\hline $\begin{array}{c}\text { Project Finance } \\
\text { (Structured Finance) }\end{array}$ & $\begin{array}{l}\text { - private investment initiatives (PFI) } \\
\text { - mixed “public-private” partnerships (PPP) }\end{array}$ \\
\hline Risk Management & $\begin{array}{l}\text { - industrial risk management services } \\
\text { - finacial risk management services } \\
\text { - advisory services for risk measurement and coverage }\end{array}$ \\
\hline
\end{tabular}

Source: Capizzi (2006) 
Table 2. Total and average market value of the firms in the sample

\begin{tabular}{|c|c|c|c|c|c|c|}
\hline Country & France & Germany & Italy & Spain & UK & Total \\
\hline $\begin{array}{c}\text { Total stock } \\
\text { market value }\end{array}$ & 1895235 & 1439960 & 733610 & 1231090 & 2634580 & 7934475 \\
\hline $\begin{array}{c}\text { \% in relation to } \\
\text { GDP }\end{array}$ & $100.16 \%$ & $59.43 \%$ & $47.78 \%$ & $117.18 \%$ & $128.58 \%$ & $88.65 \%$ \\
\hline $\begin{array}{c}\text { Total market } \\
\text { value of the firms } \\
\text { in the sample }\end{array}$ & 893795 & 692228 & 293877 & 382494 & 1069371 & 3331765 \\
\hline $\begin{array}{c}\text { \% in relation to } \\
\text { stock market } \\
\text { value }\end{array}$ & $47.16 \%$ & $48.07 \%$ & $40.06 \%$ & $31.07 \%$ & $40.59 \%$ & $41.99 \%$ \\
\hline $\begin{array}{c}\text { Average market } \\
\text { value of the firms } \\
\text { in the sample }\end{array}$ & 29793 & 23870 & 9796 & 13189 & 36875 & 22665 \\
\hline $\begin{array}{c}\text { Standard } \\
\text { deviation of the } \\
\text { market value of } \\
\text { the firms in the } \\
\text { sample }\end{array}$ & 27898 & 18270 & 17591 & 17962 & 30720 & 25013 \\
\hline
\end{tabular}

Figures in millions of Euros, end 2007.

Source: Eurostat and Datastream data processed by the authors

Table 3. Proxy for estimating investment banking propensity and PIB (Propensity for Investment Banking) Indicator

\begin{tabular}{|c|c|c|c|c|c|c|}
\hline Country & France & Germany & Italy & Spain & UK & Total \\
\hline \multicolumn{7}{|c|}{ PIB } \\
\hline Average value & $57.86 \%$ & $43.81 \%$ & $35.71 \%$ & $45.54 \%$ & $53.93 \%$ & $46.81 \%$ \\
\hline Standard deviation & $16.50 \%$ & $16.85 \%$ & $15.92 \%$ & $18.21 \%$ & $16.30 \%$ & $18.35 \%$ \\
\hline \multicolumn{7}{|c|}{ Proxy for estimating PIB (average value) } \\
\hline $\begin{array}{l}\text { I) Number of firms in } \\
\text { the group }\end{array}$ & 882 & 680 & 568 & 650 & 550 & 667 \\
\hline $\begin{array}{l}\text { II) Number of M\&As } \\
\text { (Buyer) (2005-2007) }\end{array}$ & 7.63 & 6.40 & 4.20 & 5.67 & 7.90 & 6.36 \\
\hline $\begin{array}{l}\text { III) Number of M\&As } \\
\text { (Seller) (2005-2007) }\end{array}$ & 7.90 & 7.07 & 3.33 & 3.63 & 4.70 & 5.33 \\
\hline IV) Number of buy backs & 50.87 & 0.40 & 1.33 & 1.07 & 185.17 & 47.77 \\
\hline V) Bonds/equity ratio & $87.61 \%$ & $42.81 \%$ & $44.23 \%$ & $41.42 \%$ & $42.84 \%$ & $51.78 \%$ \\
\hline VI) Stock volatility & $29.93 \%$ & $28.57 \%$ & $28.35 \%$ & $33.74 \%$ & $30.34 \%$ & $30.18 \%$ \\
\hline $\begin{array}{l}\text { VII) Equity holdings of } \\
\text { financial intermediaries }\end{array}$ & $23.53 \%$ & $20.47 \%$ & $13.80 \%$ & $17.21 \%$ & $52.95 \%$ & $25.59 \%$ \\
\hline
\end{tabular}

Source: Bloomberg \& Amadeus data processed by the authors

Sample consisting of the 30 largest listed non-financial firms in France, Germany, Italy, Spain and UK 
Table 4. Criteria for numerical conversion of the BVDEP Independent Indicator

Source: authors' own work

\begin{tabular}{|c|c|}
\hline BVDEP $_{\text {ii }}$ & Associated Numerical Value \\
\hline $\mathrm{A}+$ & 10 \\
\hline $\mathrm{A}$ & 9 \\
\hline $\mathrm{A}-$ & 8 \\
\hline $\mathrm{B}+$ & 7 \\
\hline $\mathrm{B}$ & 6 \\
\hline $\mathrm{B}-$ & 5 \\
\hline $\mathrm{C}+$ & 4 \\
\hline $\mathrm{C}$ & 3 \\
\hline $\mathrm{D}$ & 2 \\
\hline
\end{tabular}

Table 5. Results from quantitative conversion of the BVDEP Independence Indicator

\begin{tabular}{|l|c|c|c|c|c|c|}
\hline \multicolumn{1}{|c|}{ Country } & France & Germany & Italy & Spain & UK & Total \\
\hline Number of Observations & 30 & 30 & 30 & 30 & 30 & 150 \\
\hline Average value & 8.00 & 7.46 & 4.00 & 5.67 & 8.80 & 6.79 \\
\hline Standard deviation & 3.184 & 3.501 & 3.778 & 3.769 & 2.681 & 3.770 \\
\hline
\end{tabular}

Sample consisting of the 30 largest listed non-financial enterprises in France, Germany, Italy, Spain and UK. The results are based on the application of the conversion criteria shown in Table 4.

Source: Amadeus data processed by the authors.

Table 6. Sample composition and Governance Indicator (DIR: Presence of independent directors)

\begin{tabular}{|c|c|c|c|c|c|c|}
\hline Country & France & Germany & Italy & Spain & UK & Total \\
\hline Total sample & 30 & 30 & 30 & 30 & 30 & 150 \\
\hline Financial enterprises & 5 & 6 & 14 & 6 & 8 & 39 \\
\hline Data not available & 2 & 24 & & & & 26 \\
\hline \multicolumn{7}{|c|}{ DIR } \\
\hline Average & $49.87 \%$ & - & $49.77 \%$ & $31.44 \%$ & $65.08 \%$ & $48.58 \%$ \\
\hline Standard Deviation & $19.74 \%$ & - & $22.57 \%$ & $16.08 \%$ & $12.71 \%$ & $21.45 \%$ \\
\hline
\end{tabular}

Sample consisting of the 30 largest listed non-financial firms in France, Germany, Italy, Spain and UK. DIR (Percentage of independent directors on the board).

Source: Data from Farina, Schwizer, Stefanelli (2009) processed by the authors.

Table 7. Profitability Indicator (ROE)

\begin{tabular}{|c|c|c|c|c|c|c|}
\hline Country & France & Germany & Italy & Spain & UK & Total \\
\hline No. of observations & 30 & 30 & 30 & 30 & 30 & 150 \\
\hline Average & $24.60 \%$ & $26.39 \%$ & $23.22 \%$ & $30.60 \%$ & $47.04 \%$ & $29.27 \%$ \\
\hline Standard Deviation & $16.07 \%$ & $14.02 \%$ & $19.45 \%$ & $30.39 \%$ & $40.41 \%$ & $25.85 \%$ \\
\hline
\end{tabular}

Sample consisting of the 30 largest listed non-financial enterprises in France, Germany, Italy, UK and Spain. 2007 data. Source: Amadeus data processed by the authors 
Table 8. Market valuation indication (PBV - Price to Book Value)

\begin{tabular}{|c|c|c|c|c|c|c|}
\hline Country & France & Germany & Italy & Spain & UK & Total \\
\hline No. of observations & 30 & 30 & 30 & 30 & 29 & 149 \\
\hline Average & 2.640 & 3.118 & 2.077 & 4.209 & 4.777 & 3.317 \\
\hline Standard Deviation & 1.863 & 2.924 & 1.307 & 3.653 & 2.983 & 2.862 \\
\hline
\end{tabular}

Sample consisting of the 30 largest listed non-financial firms in France, Germany, Italy, Spain and UK with the exclusion of one outlier. 2007 data.

Source: Amadeus data processed by the authors

Table 9. Regression between investment banking propensity and ownership structure

\begin{tabular}{|c|c|c|}
\hline Independent Variable & \multicolumn{2}{|c|}{ Dependent Variable: PIB } \\
\hline BVDEPii & $0.229013^{* * *}$ & $0.231595^{* * *}$ \\
\hline Intercept & $(0.036109)$ & 0.048369 \\
\hline & $0.312824 * * *$ & $0.344675^{* * *}$ \\
\hline No. of Observations & $(0.027875)$ & 0.038460 \\
\hline Adjusted R-squared & 150 & 85 \\
\hline
\end{tabular}

*** Significance: $99 \% \quad * *$ Significance: $95 \% \quad *$ Significance: $90 \% *$

Regression by the OLS method on the 30 largest listed non-financial firms in France, Germany, Italy, UK and Spain and a subsample of 85 firms. The dependent variable is PIB (Propensity for investment banking). The independent variable is BVDEPii (Indicator of management independence from shareholders). The standard errors are shown in brackets.

Table 10. Regression between investment banking propensity, corporate governance and ownership

\begin{tabular}{|c|c|c|}
\hline Independent Variable & \multicolumn{2}{|c|}{ Dependent Variable: PIB } \\
\hline DIR & $0.197029 * *$ & -0.000522 \\
\hline BVDEP $_{\mathrm{ii}}$ & $(0.088817)$ & $(0.094613)$ \\
\hline & & $0.231754^{* * *}$ \\
\hline Intercept & & $(0.056555)$ \\
\hline & $0.413517 * * *$ & $0.344816^{* * *}$ \\
\hline No. of Observations & $(0.047126)$ & $(0.046335)$ \\
\hline Adjusted R-squared & 85 & 85 \\
\hline
\end{tabular}

*** Significance: $99 \% \quad * *$ Significance: $95 \% \quad *$ Significance: $90 \% *$

Regressions by OLS method on a sample of 85 non financial firms from amongst the 30 largest listed firms in France, Germany, Italy, Spain and UK. The dependent variable is PIB (Propensity for investment banking). The independent variables are DIR (Percentage of independent directors on the board); BVDEPii (Indicator of management independent from shareholders). The standard errors are shown in brackets. 
Table 11. Regression between ROE and investment banking propensity

\begin{tabular}{|c|c|}
\hline Independent Variable & Dependent Variable: ROE \\
\hline PIB & -0.024773 \\
\hline & 0.115808 \\
\hline Intercept & $0.304336^{* * *}$ \\
\hline & 0.058199 \\
\hline No. of Observations & 150 \\
\hline Adjusted R-squared & 0.006446 \\
\hline
\end{tabular}

*** Significance: $99 \% \quad$ ** Significance: $95 \% \quad *$ Significance: $90 \% *$

Regression by OLS method on the 30 largest listed non-financial firms in France, Germany, Italy, Spain and UK. The dependent variable is ROE (Return on equity). The independent variable is PIB (Propensity for investment banking). The standard errors are shown in brackets.

Table 12. Regression between Price to Book Value and investment banking propensity

\begin{tabular}{|c|c|}
\hline Independent Variable & Dependent Variable: PBV \\
\hline PIB & -2.085763 \\
\hline & 1.271959 \\
\hline Intercept & $4.291705^{* * *}$ \\
\hline & 0.638588 \\
\hline No. of Observations & 149 \\
\hline Adjusted R-squared & 0.011283 \\
\hline
\end{tabular}

*** Significance: $99 \% \quad$ ** Significance: $95 \% \quad *$ Significance: $90 \% *$

Regression by OLS method on the 30 largest listed non-financial firms in France, Germany, Italy, Spain and UK, with the exclusion of one outlier. The dependent variable is PBV (Price to Book Value). The independent variable is PIB (Propensity for investment banking). The standard errors are shown in brackets. 